\title{
Differences in early dynamics and effects of slope aspect between naturally regenerated and planted Pinus sylvestris woodland on inland dunes in Poland
}

\section{Piotr Sewerniak}

\section{Introduction}

Scots pine (Pinus sylvestris) is the most widely distributed species of the Pinaceae family, and a commercially important forest tree in large parts of its native range. Due to its high stress tolerance, it is also widely planted to stabilize and restore habitats in sites with poor conditions, for example, to fix dunes with dry, poor sandy soil (Piotrowska 1988, Cedro et al. 2013) However, young pine stands are often severely threatened by extreme stress or

\begin{abstract}
There is little knowledge of the effects of landform relief on early growth dynamics and competitive interactions of Pinus sylvestris (Scots pine) stands on inland dunes, which could potentially be substantial. The goal of this study was to examine and compare early dynamics (based on growth parameters and properties of the understorey vegetation) and the effects of slope aspect in naturally regenerated and pine-planted woodland on inland dunes in northern Poland. Growth parameters, tree density, and understorey vegetation were monitored on north- and south-facing slopes in a 26.3 ha post-fire area with natural secondary succession and eight even-aged pine-planted stands, 5-34 years old. Clear differences were detected between the woodland types, in both growth parameters of pines with similar ages and effects of slope aspect on the pines. In the natural regeneration area north-facing slopes provided favorable conditions for natural encroachment by pines. Tree density was higher, and the pines were taller and thicker, on north-facing than on southfacing slopes. In contrast, in the pine-planted area pines were larger on southfacing slopes, although growth conditions were less favorable than on northfacing slopes. However, in the pine-planted area the north-facing slopes had significantly higher herb cover, dominated by Deschampsia flexuosa, indicating that even the presence of a relatively low grass species can impede early growth of Scots pine. The understorey species composition differed in the natural regeneration area, being dominated by Calluna vulgaris on north-facing slopes and Corynephorus canescens on south-facing slopes. The results reveal that interactions between landform, natural dynamics, planting practices, and competitive interactions in woodlands on inland dunes are complex, and should be considered in efforts to manage them efficiently.
\end{abstract}

Keywords: Scots Pine, Growth Dynamics, Dunes, Slope Aspect, Forest Succession, Pine Plantations, Sandy Areas, Podzols

disturbance in such environments (Zhu et al. 2003, 2006, Menkis et al. 2012). Thus, thorough understanding of the biotic and abiotic processes in Scots pine forests is needed, particularly those in "high risk environments" during early development stages, when the young trees are most susceptible to stresses and disturbances. In early development phases, young trees and understorey vegetation (shrubs and herbaceous weeds) strongly compete for the nutrients, water and light required for

Department of Soil Science and Landscape Management, Nicolaus Copernicus University, Lwowska 1, 87-100 Torun (Poland)

@ Piotr Sewerniak (sewern@umk.pl)

Received: Jun 02, 2015 - Accepted: Mar 01, 2016

Citation: Sewerniak P (2016). Differences in early dynamics and effects of slope aspect between naturally regenerated and planted Pinus sylvestris woodland on inland dunes in Poland. iForest 9: 875-882. - doi: 10.3832/ifor1728-009 [online 2016-06-17]

their growth and survival, in both natural woodlands during succession (Prach \& Pyšek 2001, Ciurzycki 2004, Picon-Cochard et al. 2006) and managed forests (Andrzejczyk 2000, Sewerniak et al. 2012). The competition is most evident under extreme conditions, e.g., when soil moisture is generally low (Watt et al. 2003, Marzano et al. 2012), a typical characteristic of the dry, sandy soils of inland dunes (Zhu et al. 2006, Jankowski 2010, Sewerniak et al. 2011). Fire can help tree species compete with understorey vegetation (Ascoli \& Bovio 2010), and reportedly facilitate natural regeneration of Scots pine (Hille \& Ouden 2004, Marozas et al. 2007). However, fires can also impair Scots pine's encroachment of a new ecosystem. For example, slow-moving fires can increase the temperature of Scots pine seeds to over $90{ }^{\circ} \mathrm{C}$ and harm their germinative capacity, thus helping competitor species (Nuñez et al. 2003).

Landform relief is a major factor in plant growth and dynamics, as it determines both the gradient and aspect of slopes, and thus the amount of solar radiation which strongly influence moisture and tem- 
perature regimes (Cantlon 1953, Yimer et al. 2006, Sewerniak et al. 2011). However, as slope aspect has the strongest effects on vegetation in large-scale relief forms, previous research on relief's effects on plant growth has mainly focused on mountainous areas (Ochrymowicz 1963, Fekedulegn et al. 2003, Rezaei \& Gilkes 2005, Calvo et al. 2008, Socha 2008, Bravo et al. 2011). There has been less investigation of its effects in dune environments, which have relatively slight relief, and most of this investigation has focused on coastal dune ecosystems (Piotrowska 1988, Acosta et al. 2000, Tilik et al. 2011, Menkis et al. 2012, Cedro et al. 2013). Some slope-related variations in the vegetation and microclimate of inland dune environments have been reported (Jankowski 2010, Sewerniak et al. 2011), but more detailed observation and analysis of the mechanisms responsible for the observed variations are required.

In the northern hemisphere, north-facing slopes receive less solar radiation than south-facing slopes, and thus generally have a more humid microclimate, more fertile soil, and lower temperatures (Cantlon 1953, Egli et al. 2006, Sewerniak et al. 2011, 2012, Sigua et al. 2011). Hence, aspect also strongly influences the species composition of trees, shrub communities, and herb layers (Yimer et al. 2006, Jankowski 2010, Sewerniak et al. 2011). Furthermore, it may significantly affect timber production; notably, many studies have shown that stands grow faster on north-facing slopes than on south-facing slopes in northern temperate forests due to their higher soil moisture and fertility (Ochrymowicz 1963, Fekedulegn et al. 2003, Socha 2008).

Ecological approaches are increasingly applied in land restoration programs and forest management, and it has been suggested that silvicultural practices should reflect the dynamics of naturally developing ecosystems (Shorohova et al. 2009). A potentially valuable way to identify practices that may be suitable for such strategies is to compare processes in natural woodlands and managed forests (Prach \& Pyšek 2001). As most inland dune habitats of Central Europe are currently covered by even-aged, planted Scots pine monocultures, extensive areas with natural vegetation are scarce, and the only such area remaining in Poland is the Torun artillery training ground, in the northern part of the country.

The objectives of this study were to examine and compare early dynamics (based on growth parameters and properties of the understorey vegetation) and effects of slope aspect in naturally regenerated and pine-planted woodland on inland dunes in Poland. It was hypothesized that early dynamics would differ between the two woodland types, that slope aspect would affect the dynamics, and that the results would provide valuable insights for managing forests and reforesting dune environments.

\section{Materials and methods}

\section{Site description and experimental design}

The study was conducted at the Torun artillery training ground $\left(52^{\circ} 55^{\prime} \mathrm{N}, 18^{\circ} 36^{\prime} \mathrm{E}\right.$ - Fig. 1), located in one of the largest inland dune fields of Poland. The dominant soils here are sandy, acidic, dry and nutrientpoor Podzols (Bednarek \& Jankowski 2006, Sewerniak et al. 2011). The mineral material

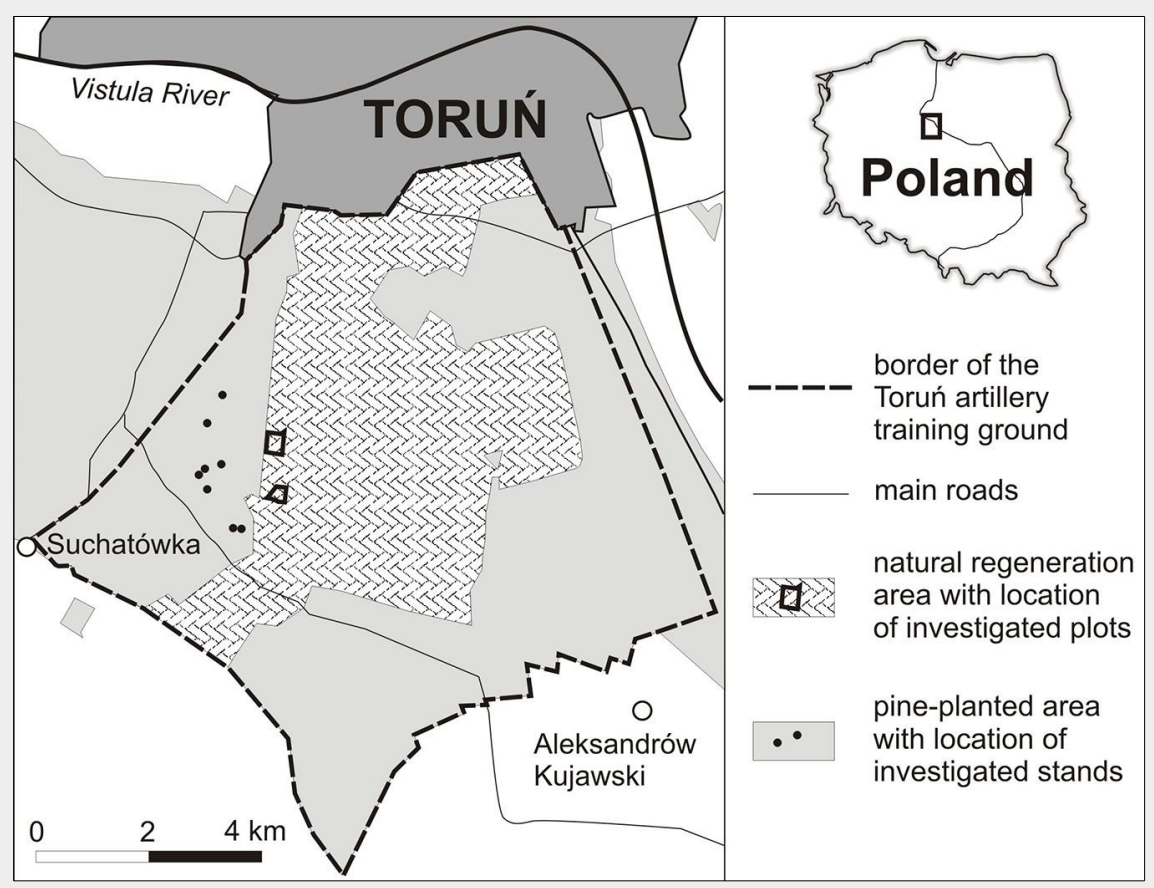

Fig. 1 - Location of the study area. of the soil has very homogeneous composition and texture, being highly dominated (85-99\%) by quartz (Jankowski 2010), and approximately $80 \%$ of the particles are in the $0.1-0.25 \mathrm{~mm}$ fraction (Sewerniak et al. 2011). The study area has a transitional type of climate, between oceanic and continental. The mean annual temperature is $7.9^{\circ} \mathrm{C}$, with monthly means ranging from -2.2 to $18.1^{\circ} \mathrm{C}$ in January and July, respectively. The average annual precipitation is $522.5 \mathrm{~mm}$, July being the wettest month. The mean length of the annual growing season at the study area is 218 days (Wójcik \& Marciniak 2006).

For the comparative study two plots were established in a natural regeneration area (NRA) and pairs of plots in eight stands in a pine-planted area (PPA). The two NRA plots, covering 26.3 ha in total and spaced approximately $1 \mathrm{~km}$ apart (Fig. 1), were established for inclusion in a longterm research program in 2011, when all trees in the plots at least $1 \mathrm{~m}$ tall were measured (Sewerniak \& Mendyk 2015).

The studied NRA had been deforested for military purposes in the 1950s, and since then the main factors influencing development of the vegetation had been natural secondary succession and fires that had periodically retarded the succession. As the plots were in a military area, no forest management practices (soil preparation, thinnings etc.) had been applied to either of them for decades. The last two fires in the NRA (both of which burned the two study plots) occurred in 1989 and 1991. The fires were not very severe as there had been relatively little fuel to burn, because in the late 1980 on only about 30 years had passed since deforestation in the 1950s. Thus, the vegetation in the studied plots was similar to the vegetation observed in 2011. Nevertheless, the fires eliminated most of the trees on both plots, and in 2011 only eight pre-fire pines were present in the whole 26.3 ha study area. The oldest two of these trees were 41 and 45 years old, and the other six were younger than 30 years. When the measurements were taken in 2011 the plots were covered by stands with a loose tree canopy dominated by pines (Fig. 2) with ages quite evenly distributed across the range $0-22$ years (Tab. 1 ), reflecting the gradual encroachment of trees in the NRA in the years following the last fires. As the potential natural vegetation on the studied dunes is subcontinental Peucedano-Pinetum forest (Chojnacka et al. 2010), Pinus sylvestris accounted for most $(82 \%)$ of the trees encroaching in the plots. Silver birch (Betula pendula) accounted for another $17 \%$, and percentages of other species were minimal (Sewerniak \& Mendyk 2015).

The PPA plots were established in the external zone of the Torun artillery training ground, where the forest was divided into even-aged sections of $P$. sylvestris stands representing different age classes. The stands were usually pine monocultures 
with small proportions of other species, mainly B. pendula. Unlike forest in the NRA, stands in the PPA had been subjected to standard forest management practices. Eight PPA stands were selected to cover the age range of most pines growing in the NRA $(5,6,7,10,14,17,22$ and 34 years old younger stands were excluded, because pines in them were much shorter than 1 $\mathrm{m})$. All of the PPA stands selected for inclusion in the study had replaced at least one previous generation of clear-cut forest, had not been exposed to fire for at least 50 years, and were located on a dune with a south-facing and a north-facing slope, both of which had received identical silvicultural treatments since planting.

All of the study plots, representing both woodland types, were located within $3 \mathrm{~km}$ of each other (Fig. 1). They were situated beside army training grounds, and vegetation development had not been impacted by military activities (e.g., explosions etc.) in recent decades. The mean relative height of the investigated dunes is about 8 $\mathrm{m}$. The only source of water for the plants on the dune landforms is precipitation, as no groundwater was available to the roots.

\section{Data collection and analysis}

In both NRA plots the GPS location, total height $(\mathrm{H})$ and diameter at $5 \mathrm{~cm}$ above ground level (D) of all pines at least $1 \mathrm{~m}$ tall (700 in total) were measured in autumn 2011. Tree height was determined using a calibrated pole or a Vertex IV hypsometer (Haglöf, Långsele, Sweden), as appropriate, and the diameter using a caliper. In addition, the height of the lowest living branch $\left(\mathrm{H}_{1}\right)$ of 177 pines representing the full-size range of trees included in the study was measured, and their ages were determined by counting the tree-rings in cores extracted with an increment borer. To determine whether trees were on a north-facing or a south-facing slope the GPS positions of NRA pines were transferred to $\operatorname{ArcGIS}^{\circledast}$ 9.3 (ESRI, Redlands, CA, USA). North- and south-facing slopes were defined as polygonal areas with azimuths of $315-45^{\circ}$ and $135-225^{\circ}$, respectively, and a minimum inclination of $5^{\circ}$. In total, 112 such polygons were identified, 60 representing north-facing slopes and 52 representing south-facing slopes, supporting 180 and 69 pines, respectively (Tab. 2).

To obtain tree measurements in the PPA stands 16 rectangular plots were established, two in each stand, one on a northfacing slope and the other on a south-facing slope (Tab. 3). As silver birch strongly affects the growth of surrounding trees (Zarzycki 1979), plots were only established in parts of the stands where the only trees were Scots pines; consequently, the plot area varied from 48 to $92 \mathrm{~m}^{2}$, due to restrictions imposed by the presence of silver birch. In 2013, the $H, H_{1}$, and D of all the pines in the plots ( 623 in total) were measured.

Using the initial measurements, the slen-

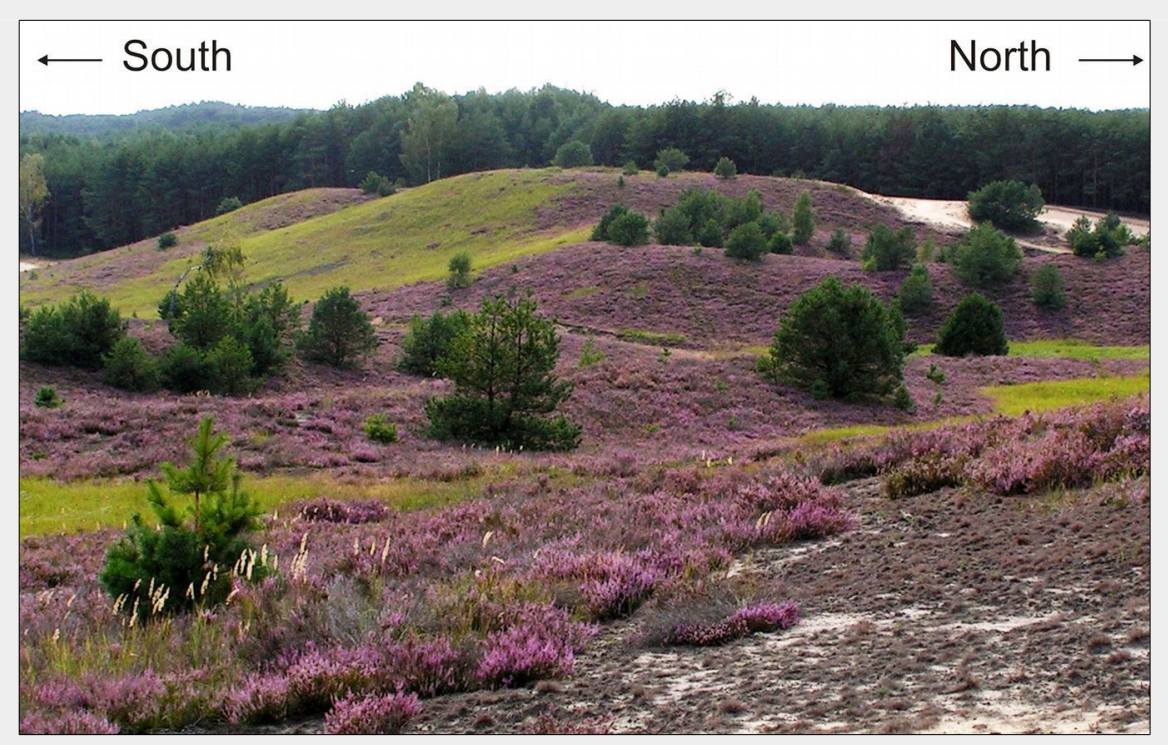

Fig. 2 - A study plot located in the natural regeneration area (NRA). Stands that are part of planted and managed forests can be seen in the background.

derness ( $\mathrm{H} / \mathrm{D}$ ratio) and relative crown length ( $R C L$, obtained by dividing the crown length, $\mathrm{H}-\mathrm{H}_{1}$, by $\mathrm{H}$ then multiplying by 100 ), were calculated for all the measured pines in both woodland types. Moreover, to avoid drilling increment bores in all pines in the NRA, the relationships between age and both height and diameter were calculated by linear regression. Age was found to be more strongly related to diameter $\left(R^{2}=0.84\right)$ than height $\left(R^{2}=0.81\right)$,

Tab. 2 - Characteristics of natural regeneration area polygons, obtained with ArcGIS, representing slopes with northerly and southerly aspects. (SD): standard deviation.

\begin{tabular}{lcc}
\hline \multirow{2}{*}{ Variable } & \multicolumn{2}{c}{ Slope aspect } \\
\cline { 2 - 3 } & Northerly & Southerly \\
\hline Number of polygons & 60 & 52 \\
Mean $\left( \pm\right.$ SD) area of a polygon $\left(\mathrm{m}^{2}\right)$ & $526 \pm 639$ & $1122 \pm 3240$ \\
Mean $( \pm$ SD) number of pines in a polygon & $3.0 \pm 5.2$ & $1.3 \pm 3.5$ \\
Total number of pines in all polygons & 180 & 69 \\
\hline
\end{tabular}

Tab. 3 - Characteristics of stands in plots established in the pine-planted area (PPA).

\begin{tabular}{ccccc}
\hline $\begin{array}{c}\text { Age of stand } \\
\text { (years) }\end{array}$ & $\begin{array}{c}\text { Slope } \\
\text { aspect }\end{array}$ & $\begin{array}{c}\text { Plot area } \\
\left(\mathbf{m}^{2}\right)\end{array}$ & $\begin{array}{c}\text { Number } \\
\text { of pines }\end{array}$ & $\begin{array}{c}\text { Tree density } \\
\left.\text { (pines ha } \mathbf{~}^{-2}\right)\end{array}$ \\
\hline 5 & Northerly & 66 & 44 & 6687 \\
& Southerly & 58 & 39 & 6667 \\
\hline 6 & Northerly & 50 & 34 & 6800 \\
& Southerly & 50 & 32 & 6400 \\
\hline 7 & Northerly & 90 & 55 & 6119 \\
& Southerly & 90 & 60 & 6675 \\
\hline 10 & Northerly & 81 & 55 & 6834 \\
& Southerly & 92 & 52 & 5662 \\
\hline 14 & Northerly & 50 & 33 & 6571 \\
& Southerly & 49 & 32 & 6492 \\
\hline 17 & Northerly & 57 & 31 & 5366 \\
& Southerly & 48 & 25 & 5164 \\
\hline 22 & Northerly & 74 & 33 & 4478 \\
& Southerly & 82 & 31 & 3758 \\
\hline 34 & Northerly & 174 & 32 & 1839 \\
& Southerly & 190 & 35 & 1842 \\
\hline
\end{tabular}


so the ages of pines that were not drilled in the NRA plots were estimated (in years) using the equation:

Age $=-0.0096 \cdot D^{2}+0.7414 \cdot D+5.1723$

where $D$ is the diameter (in $\mathrm{cm}$ ) taken at 5 $\mathrm{cm}$ above the ground level.

The understorey vegetation of both woodland types was also investigated. In the PPA stands a plot was established in the middle part of each studied slope, while in the NRA six plots were established on both north-facing and south-facing slopes. All plots were $200 \mathrm{~m}^{2}$ in area and there were 28 in total, 12 in the NRA and 16 in the PPA. In each plot herb cover was measured as a percentage and vascular species composition was determined by the Braun-Blanquet method (Braun-Blanquet 1964). All of this work was performed during the 2013 growing season.

Environmental conditions were indirectly assessed by a bio-indication technique based on the weighted abundances of specific plant species as indicators of positions along environmental gradients (Ellenberg et al. 2001). Such approach has been extensively used in ecological studies (Lawesson 2000, Halarewicz \& Zolnierz 2014). Using indicator values proposed for the vascular plants of Central Europe by Ellenberg et al. (2001), indices were calculated for the ecological variables light $(\mathrm{L})$, temperature $(\mathrm{T})$, continentality $(K)$, moisture $(F)$, soil reaction $(\mathrm{R})$ and nitrogen $(\mathrm{N})$ for each of the 28 plots where understorey vegetation properties were investigated. Salinity was excluded as it is only relevant for saline soils, which were not present at the study site. The latin names of plant species follow Flora Europaea (Tutin et al. 1993).

Statistical analysis

Non-parametric tests were used to test for differences in mean values of parameters between groups. Differences in measured variables of pines growing on northand south-facing slopes were evaluated using the Mann-Whitney $U$ test. Pooled data for all of the pines in the 60 polygons on north-facing slopes and 52 polygons on south-facing slopes in the NRA were used for this comparison, but in the corresponding PPA comparison pines on north- and south-facing slopes in each stand were compared separately, as these even-aged stands differed in age. The Mann-Whitney $U$ test was also used to assess the difference in tree density between north- and south-facing slopes in the NRA, but not the PPA, where the tree density was strongly influenced by the forest management practices, in addition to natural factors. Furthermore, it was used to assess the difference in mean herb cover between plots on six north-facing and six south-facing slopes in the NRA, and between plots on northfacing and south-facing slopes in the eight focal stands in the PPA. The Kruskal-Wallis test was used to assess the significance of differences in the Ellenberg indicator values for all 28 plots where the understorey vegetation was characterized. The statistical analyses were performed using the software package STATISTICA ${ }^{\circledast}$ version 9.0 (StatSoft, Tulsa, OK, USA). Detected differences were deemed significant if $P<0.05$, and errors indicated in the text with \pm symbols after mean values are standard deviations.

The differences in understorey vegetation species composition among the 28 plots were also analyzed by ordination techinques using the CANOCO package ver. 4.5 (Ter Braak \& Smilauer 2002), after transforming cover values obtained for species with the Braun-Blanquet scale into ordinal scale values as follows: $r \rightarrow 1,+\rightarrow 2$, $1 \rightarrow 3,2 \rightarrow 5,3 \rightarrow 7,4 \rightarrow 8,5 \rightarrow 9$ (Van Der Maarel
1979). Next, the length of the environmental gradient for plant occurrence was determined by Detrended Correspondence Analysis (DCA). The length was 3.846 SD (standard deviation) units and the pattern of vascular plant composition was evaluated by Principal Component Analysis (PCA - Ter Braak \& Smilauer 2002).

\section{Results}

Comparison of pine growth parameters in the two woodland types

There were clear differences in pine dimensions between the woodland types, which became more pronounced with increases in age. The parameters of young pines up to 7 years old were similar at both sites, but as the trees aged, they diverged (Fig. 3). Furthermore, pines in PPA stands tended to be taller but thinner (thus having a higher slenderness ratio, H/D) than those of corresponding ages in the NRA (as also shown in Fig. 3).

The slope aspect affected the growth dynamics of young pines, in both woodland types, but the effects qualitatively differed and were stronger in the NRA than in the PPA. In the PPA stands, trees growing on south-facing slopes generally had significantly higher mean $\mathrm{H}$ and $\mathrm{D}$ values than those growing on north-facing slopes (Fig. 4a, Fig. 4b). Furthermore, in five of the eight studied stands, trees on north-facing slopes had higher $(P<0.01)$ slenderness ratios than trees of the same age on southfacing slopes, while in the other three stands there was no significant betweenslope difference in slenderness ratio (Fig. 4c). The only considered growth parameter that was not significantly related to slope aspect in the PPA was RCL, though it was usually higher for trees on south-facing slopes than for trees of the same age on north-facing slopes (Fig. 4d).

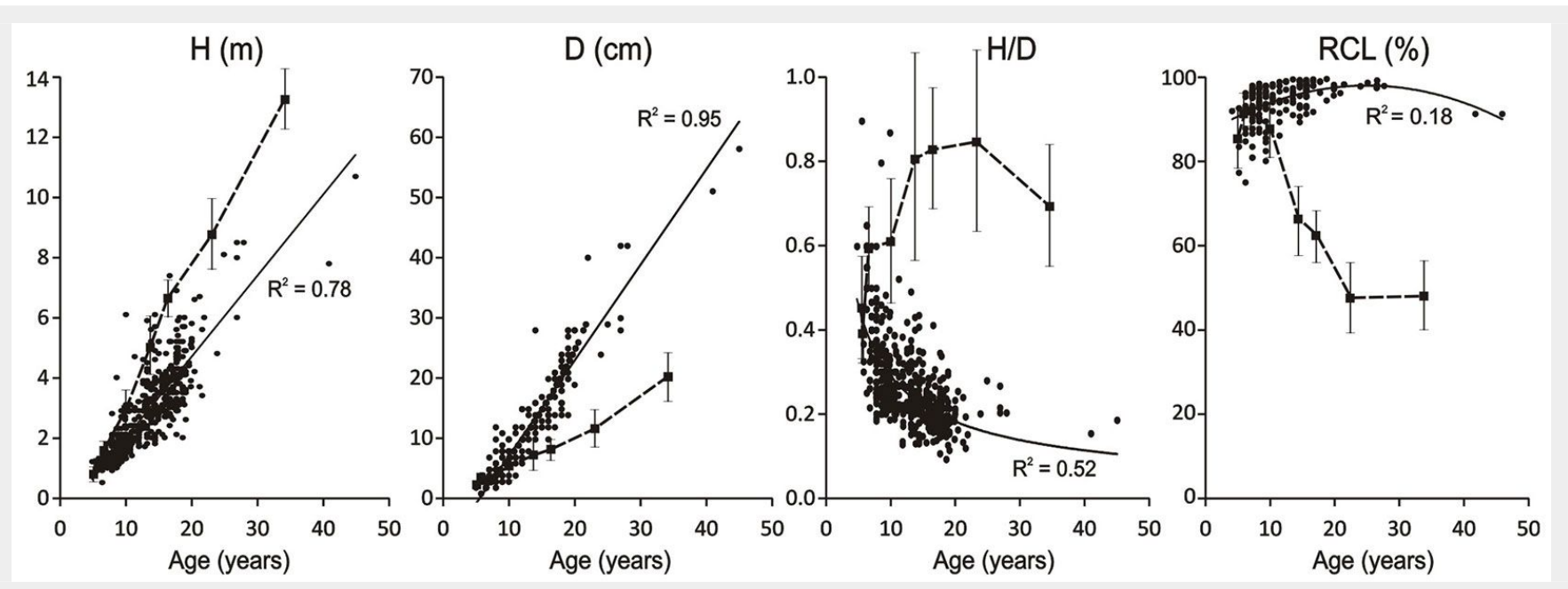

Fig. 3 - Growth parameters of pines in the two studied woodland types. (H): total height; (D): diameter at $5 \mathrm{~cm}$ above ground level; $(H / D)$ : slenderness; $(R C L)$ : relative crown length. The solid lines and circles indicate data for the natural regeneration area while dotted lines and squares indicate data for stands in the pine-planted area. The vertical lines indicate standard deviation values for the growth parameters of pines in the pine-planted area. $R^{2}$ values were obtained from linear regression of indicated growth parameters of pines in the natural regeneration area against their age. 
Fig. 4 - Growth parameters (mean + standard deviation), of pines on north-facing slopes (black bars) and south-facing slopes (gray bars) in the pine-planted area. (H): total height; (D): diameter at $5 \mathrm{~cm}$ above ground level; (H/D): slenderness; $(\mathrm{RCL})$ : relative crown length. The numbers above bars are P-values obtained by the MannWhitney $U$ test, for the differences between pines of the same age on northand south-facing slopes.
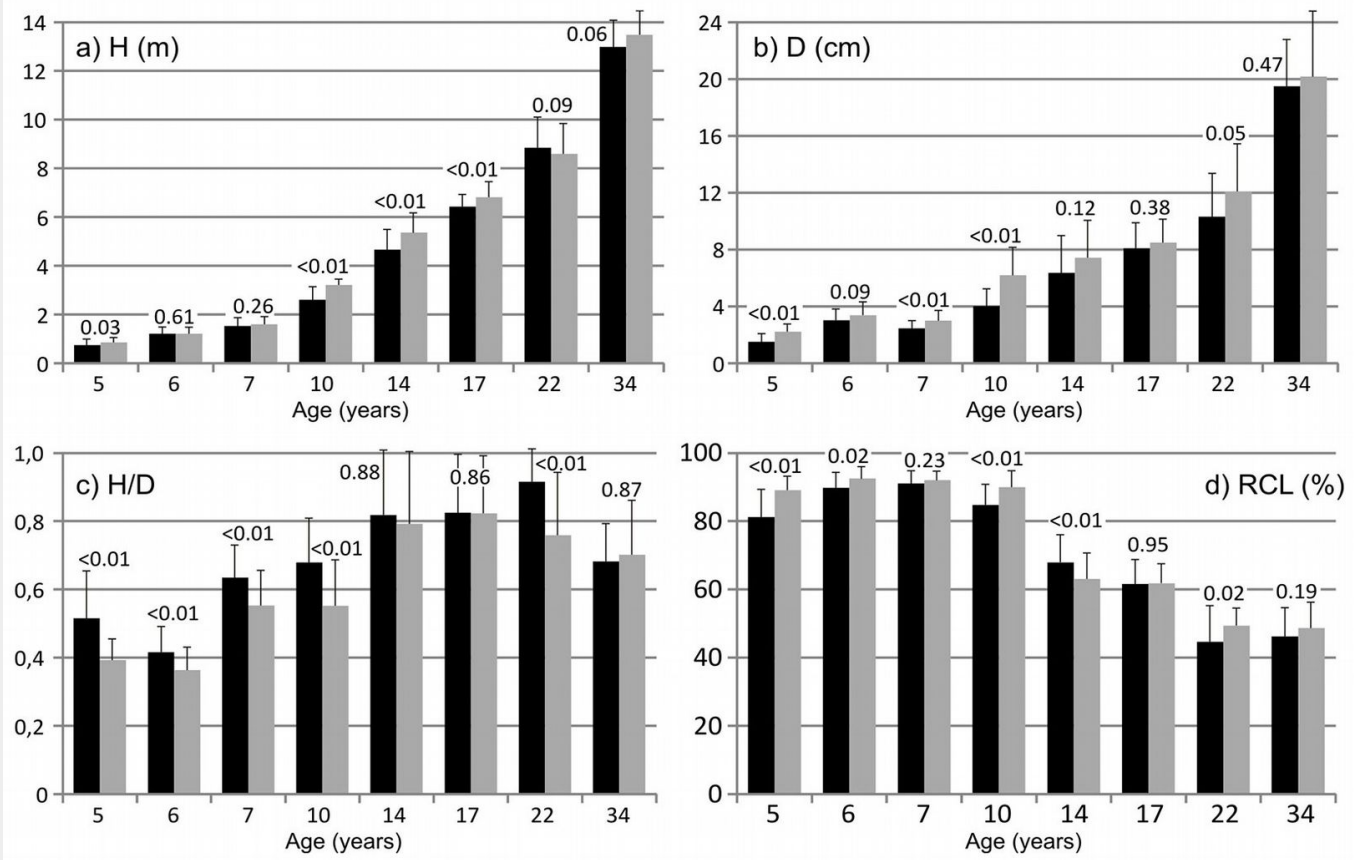

Tab. 4 - Characteristics of pines growing on slopes with northerly and southerly aspects in the natural regeneration area. $(\mathrm{H})$ : total height; (D): diameter at $5 \mathrm{~cm}$ above ground level; (H/D): slenderness; (RCL): relative crown length. Values are means \pm standard deviation. P-values were obtained after the Mann-Whitney $\mathrm{U}$ test.

\begin{tabular}{lccc}
\hline \multirow{2}{*}{ Variable } & \multicolumn{2}{c}{ Slope aspect } & \multirow{2}{*}{ P-value } \\
\cline { 2 - 3 } & Northerly & Southerly & 0.002 \\
\hline Age (years) & $13.0 \pm 4.8$ & $11.0 \pm 4.4$ & 0.01 \\
Tree density in polygons $\left(\right.$ pines $\left.^{-} \mathrm{ha}^{-2}\right)$ & $58.0 \pm 91.7$ & $14.7 \pm 40.3$ & $<0.001$ \\
\hline H $(\mathrm{m})$ & $2.79 \pm 1.43$ & $2.09 \pm 1.36$ & 0.003 \\
\hline D $(\mathrm{cm})$ & $11.9 \pm 7.6$ & $8.9 \pm 6.8$ & 0.49 \\
H/D & $0.28 \pm 0.11$ & $0.29 \pm 0.11$ & 0.84 \\
\hline RCL $(\%)$ & $93.6 \pm 4.4$ & $94.1 \pm 4.1$ & \\
\hline
\end{tabular}

Fig. 5 - PCA ordination plot showing the distribution of plots in the natural regeneration area (NRA) and pine-planted area (PPA), according to species composition of the understorey vegetation. Species abbreviations: Agr.cap - Agrostis capillaris, Bet.pen - Betula pendula, Cal.epi - Calamagrostis epigejos, Cal.vul - Calluna vulgaris, Car.are - Carex arenaria, Car.eri - Carex ericetorum, Con.maj - Convallaria majalis, Cor.can - Corynephorus canescens, Des.flex - Deschampsia flexuosa, Dry.car - Dryopteris carthusiana, Fag.sil - Fagus sylvatica, Fes.ovi - Festuca ovina, Gal.ver - Galium verum, Hie.pil - Hieracium pilosella, Hyp.per - Hypericum perforatum, Peu.ore - Peucedanum oreoselinum, Pol.odo - Polygonatum odoratum, Pot.rep - Potentilla reptans, Pru.ser - Prunus serotina, Pyr.com Pyrus communis, Que.rob - Quercus robur, Rub.pli - Rubus plicatus, Rum.ace - Rumex acetosella, Sen.vis - Senecio viscosus, Sol.vir - Solidago virgaurea, Sor.auc - Sorbus aucuparia, Thy.ser - Thymus serpyllum, Vac.myr - Vaccinium myrtillus, Vac.vit Vaccinium vitis-idaea, Vin. hir - Vincetoxicum hirundinaria.

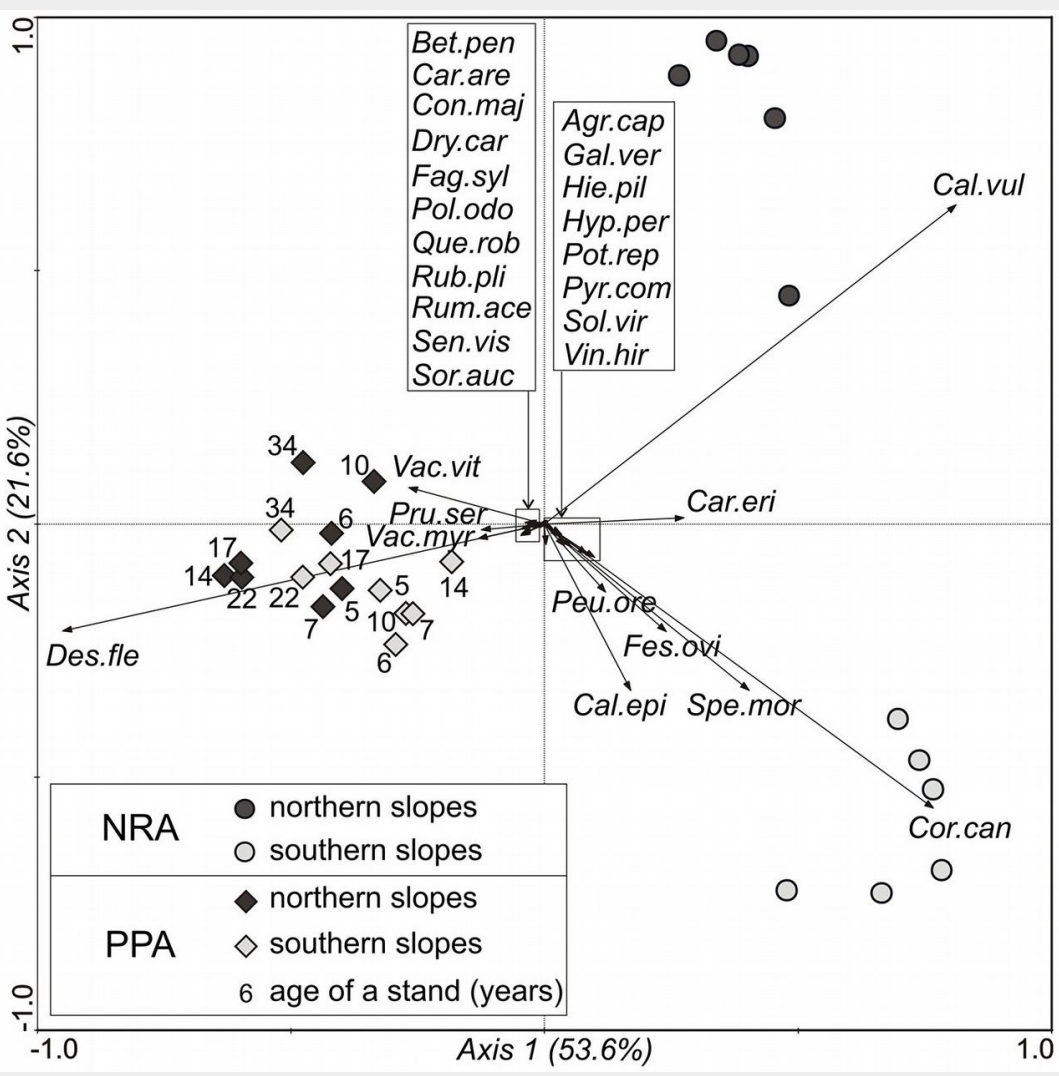




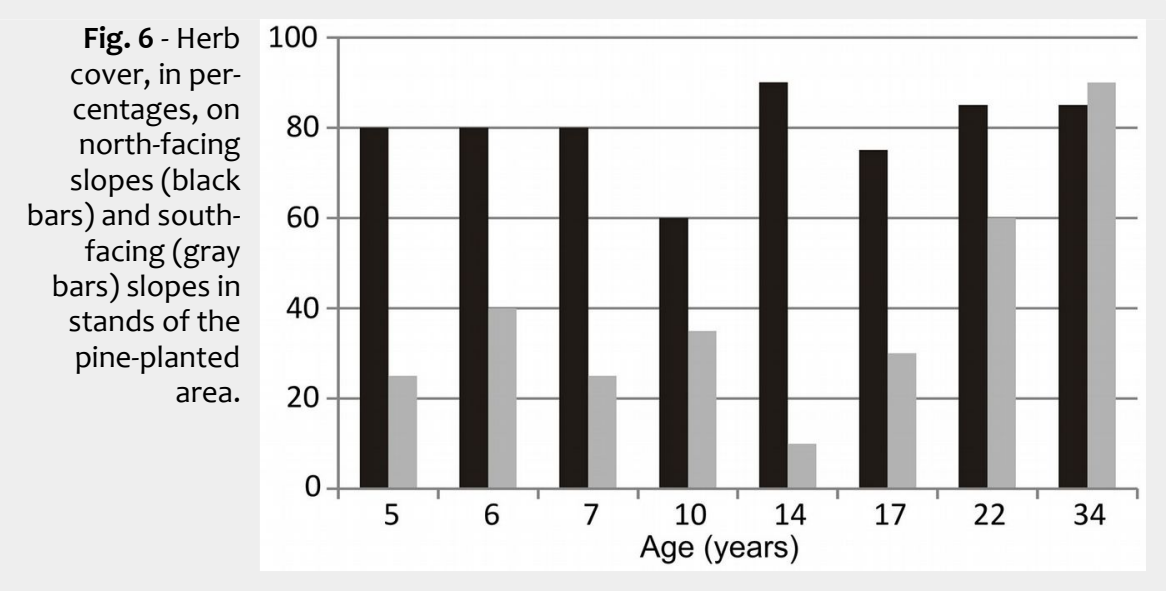

As shown in Tab. 4, in the NRA pines on the north-facing slopes were significantly older $(13.0 \pm 4.8$ vs. $11.0 \pm 4.4$ years $)$, taller $(2.79 \pm 1.43$ vs. $2.09 \pm 1.36 \mathrm{~m})$, and thicker (diameter: $11.9 \pm 7.6$ vs. $8.9 \pm 6.8 \mathrm{~cm}$ ) than on south-facing slopes, in stark contrast to relationships observed in the PPA. The tree density was also higher on the north-facing slopes ( $58.0 \pm 91.7$ vs. $14.7 \pm 40.3$ pines $h^{-1}$ ). In the NRA no significant relationship was detected between slope aspect and either slenderness or RCL (Tab. 4).

Properties of understorey vegetation in the two woodland types

The understorey vegetation species composition was clearly affected by both woodland type and slope aspect. The first axis of the PCA explains $53.6 \%$ of the total observed variance in species composition and clearly separates the two woodland types (Fig. 5), while the second axis clearly separates vegetation on north-facing and south-facing slopes in the NRA, and there is a very weak evidence of separation of the vegetation on north-facing and southfacing slopes in the PPA (Fig. 5).

In total 30 vascular plant species were found in the understorey vegetation of the investigated plots. Certain species were clearly abundant in a specific woodland type and/or on slopes with one of the aspects, as shown in Fig. 5. Deschampsia flexuosa dominated on both the north- and south-facing slopes in PPA stands, but neither of these sets of slopes in the NRA. Furthermore, aspect clearly affected the species composition of understorey vegetation in NRA plots, notably Calluna vulgaris dominated on the north-facing slopes, while Corynephorus canescens dominated on south-facing slopes.

Aspect significantly affected herb cover in the PPA, where it was twice as high on north-facing slopes than on south-facing tively; $\mathrm{P}<0.01)$, and higher on north-facing slopes in all but the oldest stand (Fig. 6). In contrast, in the NRA, although aspect clearly affected species composition, it had no effect on herb cover, which was almost identical on north-facing and south-facing slopes $(77.5 \pm 12.9 \%$ and $78.3 \pm 7.5 \%$, respectively; $\mathrm{P}=0.94)$.

Clear relationships between the calculated Ellenberg's indicator values and both topographical positions and woodland the light index $(\mathrm{L})$ values were higher for NRA plots than for PPA plots, in accordance with the more open canopy in the NRA. Moreover, in both woodland types the index was higher for south- than for north-facing slopes, but this distinction was clearer in the PPA. In both woodland types, the moisture index $(F)$ values were higher and the two indices relevant to soil fertility (reaction - R, and nitrogen - $\mathrm{N}$ ) were lower for north- than for south-facing slopes. However, no consistent differences between slope aspects in temperature $(T)$ or continentality $(K)$ indices were detected in either of the two woodland types (Tab. 5).

\section{Discussion}

The growth dynamics of Scots pine stands strongly depends on the space available to the trees in their immediate environments (Kazmierczak 2013). The deslopes overall ( $79 \pm 9 \%$ vs. $39 \pm 25 \%$, respectypes were detected (Tab. 5). As expected, tected differences in pine growth parameters between the two studied woodland types were correlated with variations in tree density at the examined plots. The canopy of a planted pine stand will close some years after planting, but before closure the juvenile trees will have similar space to seedlings in a NRA. This explains the similarities in dimensions of the youngest pines of corresponding ages in the two woodland types. However, in the older PPA stands the canopy had closed and trees had competed more intensely for light, as reflected in their relatively high $\mathrm{H}$ and $\mathrm{H} / \mathrm{D}$ values. Furthermore, such competition is stronger on north-facing slopes than on south-facing slopes, as the former receive less light, and thus the slenderness ratios $(H / D)$ are even higher. In contrast, the canopy appears to remain open longer during the development of stands in the NRA (Fig. 2), thus intraspecific competition for light does not affect pine trees' growth so strongly. Similar patterns have been observed in a comparative study on Scots pine forests growing at sites with dry, sandy soils in China (Zhu et al. 2003).

The NRA results suggest that north-facing dune slopes can offer favorable conditions for forest succession in Central Europe. Similarly, Calvo et al. (2008) found that the density and height of Pinus pinaster seedlings were higher on north-facing slopes than on south-facing slopes in the three years following a forest fire in north-west Spain. The generally higher moisture and/ or fertility of soils on north-facing slopes could explain these results (Rezaei \& Gilkes 2005, Calvo et al. 2008, Sigua et al. 2011). The Ellenberg's indicator values obtained in this study confirmed that soil moisture was higher on the north-facing slopes of the examined sites. However, as the calculated indices for soil fertility ( $R$ and $N$ ) were higher on south-facing slopes, the results suggest that soil moisture may influence tree succession on inland dunes such as those at Torun more strongly than soil fertility.

Due to favorable soil conditions, northfacing slopes have also been regarded as superior to south-facing slopes for timber production (Ochrymowicz 1963, Fekedulegn et al. 2003, Socha 2008). Thus, a surprising finding was that trees growing on north-facing slopes of even-aged PPA stands had lower mean heights and diameters than those growing on south-facing

Tab. 5 - Ellenberg's indicator values (means \pm standard deviation) for plots on northern and southern slopes in the natural regeneration area (NRA) and the pine-planted area (PPA) for the ecological variables light (L), temperature (T), continentality (K), moisture $(F)$, reaction $(R)$ and nitrogen $(N)$. P-values were obtained after Kruskal-Wallis tests.

\begin{tabular}{llcccccc}
\hline $\begin{array}{l}\text { Revegetation } \\
\text { type variant }\end{array}$ & $\begin{array}{l}\text { Slope } \\
\text { aspect }\end{array}$ & L & T & K & F & R & N \\
\hline NRA & Northerly & $7.3 \pm 0.3$ & $5.1 \pm 0.2$ & $3.8 \pm 0.2$ & $3.8 \pm 0.4$ & $1.3 \pm 0.4$ & $1.4 \pm 0.4$ \\
& Southerly & $7.4 \pm 0.2$ & $5.5 \pm 0.1$ & $4.5 \pm 0.3$ & $2.9 \pm 0.1$ & $3.2 \pm 0.4$ & $2.3 \pm 0.3$ \\
PPA & Northerly & $5.9 \pm 0.2$ & $5.6 \pm 0.4$ & $3.4 \pm 0.4$ & $4.0 \pm 0.3$ & $2.2 \pm 0.2$ & $2.7 \pm 0.4$ \\
& Southerly & $6.3 \pm 0.3$ & $5.4 \pm 0.2$ & $3.2 \pm 0.9$ & $3.5 \pm 0.4$ & $2.4 \pm 0.4$ & $3.3 \pm 0.5$ \\
P-value & - & $<0.001$ & 0.02 & 0.002 & 0.003 & $<0.001$ & $<0.001$ \\
\hline
\end{tabular}


slopes. This may have been due to two factors. First, the north-facing slopes of the studied PPA stands had a higher herb cover (largely of $D$. flexuosa) than south-facing slopes. This would have affected pine growth in the first years after planting because grasses fiercely compete with young trees for resources (Andrzejczyk 2000, González-Martinez \& Bravo 2001, Prach \& Pyšek 2001, Picon-Cochard et al. 2006). A similar relationship between grass cover and the growth dynamics of young pines on north- and south-facing slopes of inland dunes in Poland has been previously reported (Sewerniak et al. 2012). The other likely factor is access to light, as Scots pine is a photophilous species (Ellenberg et al. 2001), and the species' growth on southern slopes may be boosted by their greater insolation, which is positively correlated to photosynthesis rates in $P$. sylvestris shoots (Oleksyn 1993). Accordingly, Sewerniak et al. (2011) found that an old-growth pine stand on a south-facing dune slope had larger dimensions than a similarly aged stand on a north-facing slope at the Torun artillery training ground.

The low density of pines on south-facing slopes of the NRA can be explained by the predominance in the understorey vegetation of grasses, which prolong forest succession due to their strong competitive impact in early stages (Prach \& Pyšek 2001, Ciurzycki 2004). Furthermore, competition with herbaceous vegetation is particularly intense in environments with low water availability (González-Martinez \& Bravo 2001), such as south-facing slopes of inland dunes, where moisture contents of the topsoil may be several-fold lower than on north-facing slopes (Sewerniak et al. 2011, 2012, Sewerniak \& Jankowski 2015). Water availability has also been widely identified as a common factor affecting plant succession on dunes (Elgersma 1998, Tilik et al. 2011), and the survival, growth and development of managed forests on dry, sandy soils (Zhu et al. 2006).

The tree density in the NRA was lower than expected 20 years after a fire, as fires reportedly stimulate the natural regeneration of trees (Hille \& Ouden 2004, Marozas et al. 2007, Ascoli \& Bovio 2010). Furthermore, significantly higher densities of Scots pine seedlings have been recorded in other post-fire areas in Poland (Dobrowolska 2008, Sewerniak 2010). However, this study was conducted in a region of relatively low precipitation compared to Central European areas, and the sandy soils of the examined dune ecosystem have poor ability to retain moisture (Jankowski 2010, Sewerniak et al. 2011). These factors hinder seedling survival, especially during dry years when seedlings must compete with weeds for meager rainfall. The scarcity of sources of propagules near the study site could also have contributed to the low tree density in the NRA (Sewerniak \& Mendyk 2015). Furthermore, if the residence times of the last fires had exceeded 10 minutes in any parts of the studied plots and generated temperatures exceeding $90{ }^{\circ} \mathrm{C}$, the germinative capacity of the Scots pine seeds in seed banks could have been harmed and the competitor species favored (Nuñez et al. 2003).

\section{Conclusions}

This comparative study extends understanding of the early dynamics of Scots pine stands in inland dune woodlands, and the effects of both slope aspect and standard management. The naturally regenerated and pine-planted stands differed in both species composition of understorey vegetation and pine growth parameters, probably due to large differences in light conditions. Although inland dunes have only slight relief, the aspect was still found to influence vegetation development. The results show that secondary succession of trees proceeds more rapidly on north-facing slopes than on south-facing slopes in inland dune areas of Central Europe. Thus, the south-facing slopes would require more careful attention during attempts to fix inland dunes by establishing or restoring vegetation.

Foresters commonly view inland dunes as uniform sites for forest management, but this study has demonstrated that aspect clearly affects factors that significantly influence tree survival, growth and development on these landforms. Notably, in the pine-planted sites young pines on south-facing slopes had larger mean dimensions than those of corresponding ages on north-facing slopes. This could be due to both the favorable light conditions and lower average herb cover observed on south-facing slopes. The north-facing slopes of young pine plantations had higher weed cover, which negatively affects early Scots pine growth dynamics, particularly in regions with low precipitation. On the dry, sandy dunes of Central Europe, even the relatively low grass species Deschampsia flexuosa can hinder the early growth of Scots pine. The findings, particularly the importance of considering effects of aspect in supposedly homogeneous sites, may facilitate efficient forest management in such environments.

\section{Acknowledgements}

This work was supported by the Polish Ministry of Science and Higher Education under grant no. N N305 304840. I am grateful to the administrators of the Torun artillery training ground, both foresters and soldiers, who enabled this research to be conducted in an area that is usually closed to civilians. I would also like to thank Lukasz Mendyk for his help with the GIS analyses. The author is very grateful to two anonymous reviewers for their valuable comments and suggestions on the previous version of the manuscript.

\section{References}

Acosta A, Blasi C, Stanisci A (2000). Spatial con- nectivity and boundary patterns in coastal dune vegetation in the Circeo National Park, Central Italy. Journal of Vegetation Science 11: 149-154. doi: $10.2307 / 3236787$

Andrzejczyk T (2000). Wplyw odleglosci od sciany drzewostanu na zageszczenie i przezywalnosć nalotów sosny zwyczajnej (Pinus sylvestris L.) na zrebach zupelnych i gniazdach [The influence of the distance from the stand edge wall on density and survival of Scots pine (Pinus sylvestris L.) seedlings on clear-cuts and gap cuts]. Sylwan 144: 27-42. [in Polish with English summary]

Ascoli D, Bovio G (2010). Tree encroachment dynamics in heathlands of north-west Italy: the fire regime hypothesis. iForest 3: 137-143. - doi: 10.3832/iforo548-003

Bednarek R, Jankowski M (2006). Gleby [Soils]. In: "Torun i jego okolice. Monografia przyrodnicza" [The city of Torun and the surroundings. Nature monograph] (Andrzejewski L, Weckwerth P, Burak S eds). Wydawnictwo UMK, Torun, Poland, pp. 153-176. [in Polish with English summary]

Braun-Blanquet J (1964). Pflanzensoziologie. Grundzüge der Vegatationskunde [Plant sociology: the study of plant communities]. SpringerVerlag, Wien-New York, pp. 865. [in German]

Bravo F, Lucà M, Mercurio R, Sidari M, Muscolo A (2011). Soil and forest productivity: a case study from Stone pine (Pinus pinea L.) stands in Calabria (southern Italy). iForest 4: 25-30. - doi: 10.3832/ifor0559-004

Calvo L, Santalla S, Valbuena L, Marcos E, Tárrega $R$, Luis-Calabuig E (2008). Post-fire natural regeneration of a Pinus pinaster forest in NW Spain. Plant Ecology 197: 81-90. - doi: 10.1007/ s11258-007-9362-1

Cantlon JE (1953). Vegetation and microclimates on north and south slopes of Cushetunk Mountain, New Jersey. Ecological Monographs 3: 241-270. - doi: 10.2307/1943593

Cedro A, Bosiacka B, Mysliwy M (2013). Dendrochronological analysis of three pine species used as pioneer species to stabilize the coastal dunes of the southern Baltic coast. Baltic Forestry 19: 226-235.

Chojnacka J, Cyzman W, Nienartowicz A, Deptula M (2010). Variability of the structure and directions in the development of heaths and psammophilous grasslands within the artillery range near the city of Torun. Ecological Questions 12: 87-125. - doi: 10.12775/v10090-010-0007-y

Ciurzycki W (2004). Wplyw wybranych czynników srodowiskowych na dynamike wkraczania swierka pospolitego na górnoreglowe polany popasterskie w Tatrach Polskich [The influence of some environmental factors on the succession dynamics of the Norway spruce on the upper montane belt glades excluded from pasturage in Polish Tatra Mountains]. Sylwan 148: 20-28. [in Polish with English summary]

Dobrowolska D (2008). Odnowienie naturalne na powierzchniach uszkodzonych przez pozar w Nadlesnictwie Rudy Raciborskie [Natural regeneration on post-fire area in Rudy Raciborskie Forest District]. Forest Research Papers 69: 255-264. [in Polish with English abstract] Egli M, Mirabella A, Sartori G, Zanelli R, Bischof S (2006). Effect of north and south exposure on 
weathering rates and clay mineral formation in Alpine soils. Catena 67: 155-174. - doi: 10.1016/j. catena.2006.02.010

Elgersma AM (1998). Primary forest succession on poor sandy soils as related to site factors. Biodiversity and Conservation 7: 193-206. - doi: 10.1023/A:1008884418570

Ellenberg H, Weber HE, Düll R, Wirth V, Werner $W$ (2001). Zeigerwerte von Pflanzen in Mitteleuropa [Ecological indicator values for plants of Central Europe]. Scripta Geobotanica 18: 1-262. [in German]

Fekedulegn D, Hicks RR, Colbert JJ (2003). Influence of topographic aspect, precipitation and drought on radial growth of four major tree species in an Appalachian watershed. Forest Ecology and Management 177: 409-425. - doi: 10.1016/S0378-1127(02)00446-2

González-Martinez SC, Bravo F (2001). Density and population structure of the natural regeneration of Scots pine (Pinus sylvestris L.) in the High Ebro Basin (Northern Spain). Annals of Forest Science 58: 277-288. - doi: 10.1051/for est:2001126

Halarewicz A, Zolnierz L (2014). Changes in the understorey of mixed coniferous forest plant communities dominated by the American black cherry (Prunus serotina Ehrh.). Forest Ecology and Management 313: 91-97. - doi: 10.1016/j.for eco.2013.11.006

Hille M, Ouden J (2004). Improved recruitment and early growth of Scots pine (Pinus sylvestris L.) seedlings after fire and soil scarification. European Journal of Forest Research 123: 213218. - doi: 10.1007/s10342-004-0036-4

Jankowski M (2010). Some aspects of site conditions of heathlands in the Torun basin. Ecological Questions 12: 149-156. - doi: 10.12775/v10090010-0008-x

Kazmierczak K (2013). The current growth increment of pine tree stands comprising three different age classes. Forest Research Papers 74: 93-100. - doi: 10.2478/frp-2013-0009

Lawesson JE (2000). Danish deciduous forest types. Plant Ecology 151: 199-221. - doi: 10.1023/ A:1026504103589

Marozas V, Racinskas J, Bartkevicius E (2007). Dynamics of understorey vegetation after surface fires in hemiboreal Pinus sylvestris forests. Forest Ecology and Management 250: 47-55. doi: 10.1016/j.foreco.2007.03.008

Marzano R, Lingua E, Garbarino M (2012). Postfire effects and short-term regeneration dynamics following high severity crown fires in a Mediterranean forest. iForest 5: 93-100. - doi: 10.3832/iforo612-005

Menkis A, Lygis V, Burokiene, Vasaitis R (2012). Establishment of ectomycorrhiza-inoculated Pinus sylvestris seedlings on coastal dunes following a forest fire. Baltic Forestry 18: 33-40. [online] URL: http://www.balticforestry.mi.lt/bf /PDF_Articles/2012-18[1]/Menkis_201218(1)_33_ 40.pdf

Nuñez MR, Bravo F, Calvo L (2003). Predicting the probability of seed germination in Pinus sylvestris L. and four competitor shrub species after fire. Annals of Forest Science 60: 75-81. doi: 10.1051/forest:2002076

Ochrymowicz F (1963). Wplyw wystawy na ksztaltowanie sie zasobnosci drzewostanów bukowych [Effect of exposition on yield of beech stands]. Sylwan 107: 35-50. [in Polish with English summary]

Oleksyn J (1993). Wymian gazowa i gospodarka wodna [Gaseous exchange and water relations]. In: "Biologia sosny zwyczajnej" [Biology of Scots pine] (Bialobok S, Boratynski A, Bugala W eds). Institute of Dendrology of the Polish Academy of Sciences, Poznan-Kórnik, Poland, pp. 89-101. [in Polish with English summary]

Picon-Cochard C, Coll L, Balandier P (2006). The role of below-ground competition during early stages of secondary succession: the case of 3year-old Scots pine (Pinus sylvestris L.) seedlings in an abandoned grassland. Oecologia 148: 373-383. - doi: 10.1007/s00442-006-0379-2 Piotrowska H (1988). The dynamics of the dune vegetation on the Polish Baltic coast. Vegetatio 77: 169-175. - doi: 10.1007/BFoo045762

Prach K, Pyšek P (2001). Using spontaneous succession for restoration of human-disturbed habitats: experience from Central Europe. Ecological Engineering 17: 55-62. - doi: 10.1016/Sog258574(00)00132-4

Rezaei SA, Gilkes RJ (2005). The effects of landscape attributes and plant community on soil chemical properties in rangelands. Geoderma 125: 167-176. - doi: 10.1016/j.geoderma.2004.07. 010

Sewerniak P (2010). Analiza wplywu pozaru na wybrane cechy fitocenozy boru sosnowego w aspekcie hodowli lasu [Analysis of effect of fire on some properties of pine forest phytocenosis in aspect of silviculture]. In: "Srodowiskowe skutki pozaru lasu" [Environmental effects of forest fire] (Sewerniak P, Gonet SS eds). Polskie Towarzystwo Substancji Humusowych, Wroclaw, Poland, pp. 83-107. [in Polish]

Sewerniak P, Bednarek R, Szymanska A (2011). Ekspozycja stoków wydm w Kotlinie Torunskiej a wybrane elementy ekosystemu boru sosnowego - wstepne wyniki badan [Preliminary studies on the influence of dune-slope exposure on a pine forest ecosystem in the Torun Basin]. Forest Research Papers 72: 37-46. [in Polish with English summary]

Sewerniak P, Gonet SS, Quaium M (2012). Wplyw przygotowania gleby frezem lesnym na wzrost sadzonek sosny zwyczajnej w warunkach ubogich siedlisk Puszczy Bydgoskiej [Impact of soil preparation with rotary tiller on growth of Scots pine plants on poor sites of the Bydgoszcz Forest]. Sylwan 156: 871-880. [in Polish with English summary]

Sewerniak P, Jankowski M (2015). Deforestation increases differences in morphology and properties of dune soils located on contrasting slope aspects in the Torun military area (N Poland). Ecological Questions 21: 61-63. - doi: 10.12775/EQ.2015.009

Sewerniak P, Mendyk L (2015). Secondary succession of trees in the dune landscape of the "Glinki" long-term research area - analysis with GIS. Forest Research Papers 76: 122-128. - doi: 10.1515/frp-2015-0012

Shorohova E, Kuuluvainen T, Kangur A, Jogiste K (2009). Natural stand structures, disturbance regimes and successional dynamics in the Eurasian boreal forests: a review with special reference to Russian studies. Annals of Forest Science 66: 1-20. - doi: 10.1051/forest/2008083

Sigua GC, Coleman SW, Albano J, Williams M
(2011). Spatial distribution of soil phosphorus and herbage mass in beef cattle pastures: effects of slope aspect and slope position. Nutrient Cycling in Agroecosystems 89: 59-70. doi: 10.1007/s10705-010-9376-2

Socha J (2008). Effect of topography and geology on the site index of Picea abies in the West Carpathian, Poland. Scandinavian Journal of Forest Research 23: 203-213. - doi: 10.1080/028 27580802037901

Ter Braak CJF, Smilauer P (2002). CANOCO reference manual and CanoDraw for Windows user's guide: software for canonical community ordination (version 4.5). Microcomputer Power, Ithaca, USA, pp. 500.

Tilik M, Mandre M, Kloseiko J, Koresaar P (2011). Understorey vegetation under natural stress conditions in Scots pine forests on fixed sand dunes in southwest Estonia. Journal of Forest Research 16: 223-227. - doi: 10.1007/s10310-0110282-5

Tutin TG, Burges NA, Chater AO, Edmondson JR, Heywood VH, Moore DM, Valentine DH, Walters SM, Webb DA (1993). Flora Europaea ( $2^{\text {nd }}$ edn). Cambridge University Press, Cambridge, New York, Melbourne, Madrid, Cape Down, Singapore, São Paulo, Delhi, Dubai, Tokyo, Mexico City, pp. 581.

Van Der Maarel E (1979). Transformation of cover-abundance values in phytosociology and its effect on community similarity. Vegetatio 39: 97-114. - doi: 10.1007/BFoo052021

Watt MS, Whitehead D, Richardson B, Mason EG, Leckie AC (2003). Modelling the influence of weed competition on the growth of young Pinus radiata at a dryland site. Forest Ecology and Management 178: 271-286. - doi: 10.1016/S 0378-1127(02)00520-0

Wójcik G, Marciniak K (2006). Klimat [Climate]. In: "Torun i jego okolice. Monografia przyrodnicza" [The city of Torun and the surroundings. Nature monograph] (Andrzejewski L, Weckwerth P, Burak S eds). Wydawnictwo UMK, Torun, Poland, pp. 99-128. [in Polish with English summary]

Yimer F, Ledin S, Abdelkadir A (2006). Soil property variations in relation to topographic aspect and vegetation community in the southeastern highlands of Ethiopia. Forest Ecology and Management 232 (2006): 90-99. - doi: 10.1016/j.foreco.2006.05.055

Zarzycki K (1979). Zarys ekologii [Outline of the ecology]. In: "Brzozy. Betula L." [Birches. Betula L.] (Bialobok S ed). Institute of Dendrology of the Polish Academy of Sciences, Warszawa-Poznan, Poland, pp. 265-291. [in Polish with English summary]

Zhu JJ, Fan ZP, Zeng DH, Jiang FQ, Matsuzaki T (2003). Comparison of stand structure and growth between artificial and natural forests of Pinus sylvestris var. mongolica on sandy land. Journal of Forestry Research 14: 103-111. - doi: 10.1007/BF02856774

Zhu JJ, Kang H, Tan H, Xu M (2006). Effects of drought stress induced by polyethylene glycol on germination of Pinus sylvestris var. mongolica seeds from natural and plantation forests on sandy land. Journal of Forest Research 11: 319-328. - doi: 10.1007/s10310-006-0214-y 